\title{
Internal and External Dimensions of China's Development in the Face of Changing Contemporary International Relations
}

\author{
T. Beydina, A. Kukharsky, A. Novikova, Yu. Popov
}

\begin{abstract}
The article discusses the relevance of China's center of power within the framework of social and political changes of the contemporary world. It is stated that China's economic and military build-up is a factor of social and political changes in the international arena. Among the factors affecting political and economic changes in political system of the PRC, the article notes the influence of traditionalism and soft power. Confucian values inherent in China's management culture, involve ideological influence over Chinese form of government, which is connected with the CPC dictatorship. The article reveals the growing influence of China on global economic and political processes.
\end{abstract}

Keywords: China, international relations, social and political changes, global economy, political processes, traditionalism, power center, reform in the PRC, soft power, modernization, foreign policy strategy.

Social and political processes are problematic issues in the PRC. These processes represent a significant sphere of a human society at the national and global levels. This sphere is both a source and a factor for political developments in modern China. As G. Mirzoyan states, "political reform will provide re-branding of China`s state power and will enable to resolve a number of structural matters in the country including corruption, as well as to close the gap between the poorer farming inland provinces and the wealthier coastal ones" [1].

Specific nature of social and political changes in the PRC in the new historic era can be regarded on the basis of the concept of a "Xiaokang" society or "Harmonious society", that is shown in the article by G. V. Kondratenko "Continuation of reforms in China: from a society of "average prosperity" to a harmonious society" [2]. Changes in China are connected with the economy which forms the basis of stabilization. As A. V. Bolyatko points out, "under certain conditions unresolved border and territorial issues between the countries of Asia entail risks of the outbreaks of new conflicts[3, p.26]. Social changes are important as well. Family factor plays an important role in modernization process in the PRC. A woman (a daughter or a daughter-in-law) takes the primary responsibility for supporting elderly Chinamen. While fertility is constantly declining, gender fatigue is increasing, due to exploitation of women and absence of a developed pension system. It is clear that the elderly Chinamen are family-oriented and seek financial support from their families. Nowadays China intensifies social support for those in need. As V. V. Mikheev notes, "While commending China`s reforms from the perspective of their impact on people's life, we cannot fail to mention that China has not been liberated from a number of complex social problems inherited from pre-reform and prerevolution times. Moreover, scenario-based reform had much negative impact" [4, 89-103].

It is obvious that China has private and individual sectors of the economy with the increasing importance of controlling branch of power. Auditors, including representatives of the police, customs and public security, are appointed by the State, that leads to greater openness. On the other hand, heavy state control promotes social unrest. Increasing challenges of social and political instability would be as follows: the rise of unemployment in cities, the growth of social inequality, great rural-urban migration, the environmental disaster and population ageing. It should be noted that information on people who are born and dead is based on women's and household members' interviews. As A. Andreev pointed out: "The information gathered enables to make demographic calculations, but the reliability of the results is far below those made in civil offices. Accordingly, international agencies calculations connected with China often seem less than fully reliable. There is nothing surprising in this fact. For years UN Statistics Division has been showing life expectancy in USSR to be 70 years while in fact it was less 68" [5]. Such regular surveys correlate with population census data. The latest population census in the PRC was from 1 to 10 November 2019 and it is very significant for regulation of agriculture. According to the resident Chinese, "In many ways, such policy is very effective, since it is in fulfilment of that policy over the past four years when Chinese Government abolished agricultural tax that hadexisted for over 2000 years, 148 million pupils of primary and secondary rural school were freed from tuition fees, more than 22 million of unemployed were able to get a new job" [6].

China tends to have a harmonious world which focuses on cultural diversity, multipolar policy and preservation of the unity by means of subjection. The ideal for the "unity without harmonization" is given by O. Brooch and A. Lomanov: "In today's world it means that China will oppose any attempts to impose values by force. 
The subtext is clear: when the USA uses "hard power" in order to disseminate its values, China highlights ideas of noninterference in anyone's business and respect for diversity of ways for countries and cultures". [7]

Generally, we can sum up major changes in internal policy and economy of China over the past years of the beginning of the XXI century:

1. Construction of new housing of heightened comfort.

2. The Internet business increased employment and consumption.

3. Officials became responsible for inaction.

4. Encourage entrepreneurial thinking to innovate.

5. In order to avoid American influence, measures for creating working coalition in collaboration with Taiwan were taken.

6. The Sino-American relationship have been developing, however China is vigilant in ensuring safety for domestic culture and people's minds from the American influence.

In recent decades China's policy has been growing quite stable in accordance with political course being followed.

Regarding the competent authorities, the supreme body of the PRC is the National People's Congress (abbreviated NPC). The executive power in China belongs to the State Council. The CPC, all people's party, dominates. Political disagreements are addressed through the highest economic growth. G. Mirzayan reports that, "According to the official forecasts, the GDP growth rate should reach 7 per cent in the next years, but, according to some economists, in order to insure social stability, the GDP growth rate should have been at least 10 per cent annually" [7]. However, homogenization through economic growth leads to political instability which is connected with governance. According to A. Maslov, the director of the Moscow Centre for Strategic Studies of China, "people will get more rights at the local level. Firstly, it is the level of greater elections in legislative, executive, judicial branches of power, the election of judges and so on. Secondly, it is the empowerment of local committees which can be seen virtually on in every street, but their rights are limited by control and migration registration for local people. Thirdly, the Communist Party will preserve its influence. The theory of Three Represents will be continuously developed. It means that the party will have representatives of a broad spectrum of Chinese society, including the representatives of economy, trade, traditional intellectuals and party officials. It may also be assumed that there will be a reform of ministries and departments. For instance, many ministries, connected with commercial activity, like the Ministry of Commerce, develop into various associations. Thus, the number of organs, which are strictly regulated, decreases". [1]

Changes in the Party and in power have been occurring in the PRC. As G. Mirzayan reports, "For many years several city governments of Chongqing and the general population have made great contributions to reform and have made clear progress. However, the present Town Committee and government should think over Wang Lijun's case and learn the right lessons from it, - Wen Jiabao, Chinese prime minister, explained the perspective of the party leadership. He also added that he did not like revolutionary red songs contests. Experts believe that other neo-maoists will be in disgrace soon. Therefore, the fifth generation of Chinese leaders which will come to power this autumn can commence change the face of the Middle Kingdom". [1]

Perspectives of social and political changes have reintroduced on the agenda the issue of new global leaders. Currently the United States of America is considered to be the world leader. Discussions of "Chinese factor" and the problem of a "peaceful integration" of the PRC into the global political game leave no doubt that the XXI century will be largely determined by competitionamong the two worldwide giants, China and the USA.

China's economy strengthens its positions as a world leader. As Xin Li reports, "China's economic potential has increased fivefold whereas the urban residents' income has increased 3.1 times" [8].In terms of the parity of the currency, China's GDP achieved the highest enrolment rate in the world, overtaking the USA in 2012. According to the International Monetary Fund, China is expected to be three times greater than the USA". [9]Figure 1 represents the schematic overview of China's GDP 


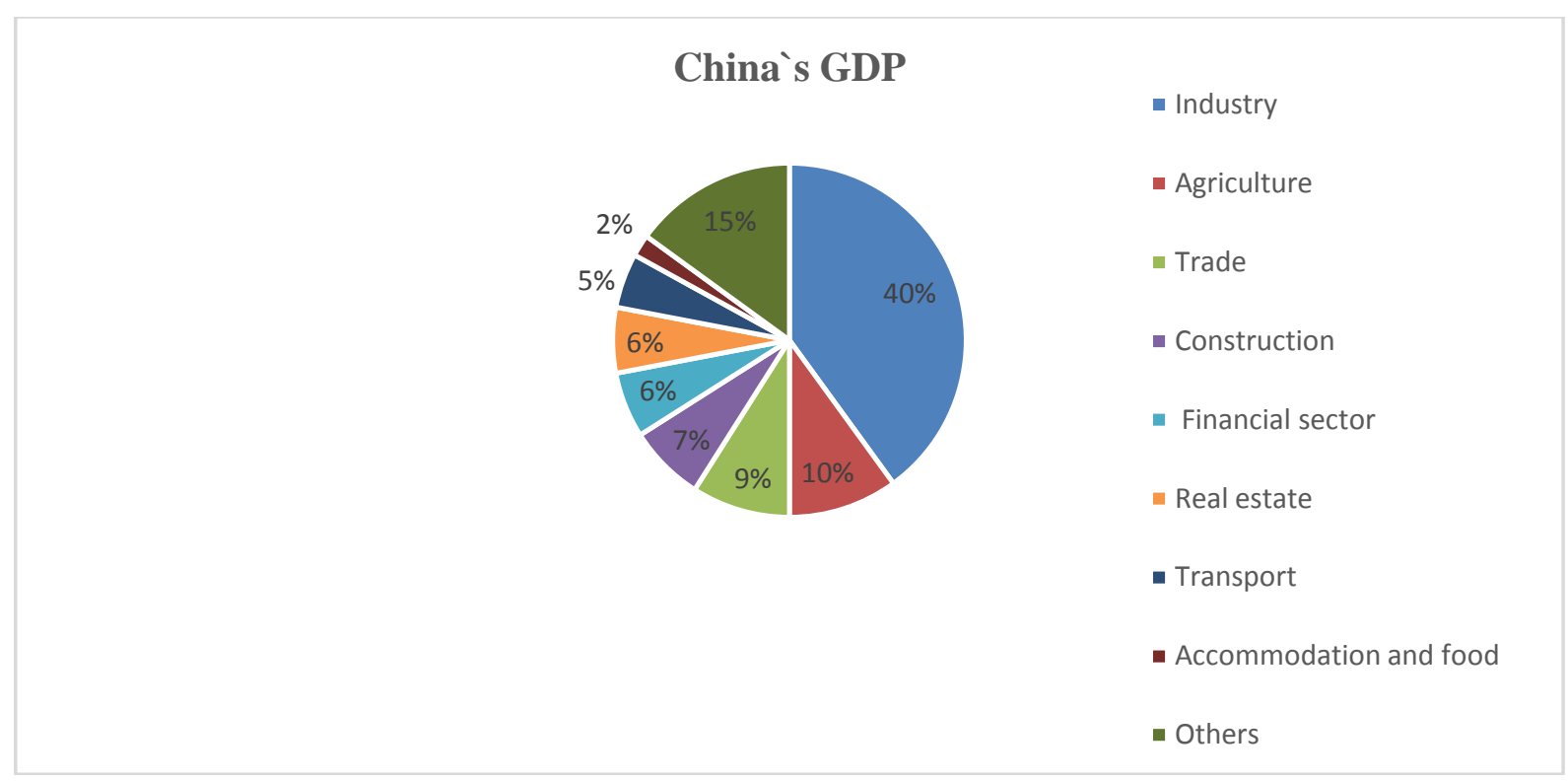

China has very high economic growth rate - about 9-10\% annually. By 2025, it is projected that China will provide more than $20 \%$ of the world GDP. This fact enables it to become the world's largest economy. As V. V Laperdina states, "Nowadays China wants to reestablish its historical role, that is to become a regional leader, thus taking part in shaping the geopolitical landscape of the world [10, p.45]. There are more than 500 million Internet users in the PRC, the country is the leader of mobile telephony, including through the establishment of Chinese Silicon Valley in Beijing.

K. M. Aksenova states: "In the modernization process China did not leave the socialist path. Four basic principles like socialism, defending democratic dictatorship of the people, the Communist Party leadership, upholding the principles of Marxism-Leninism... is the bedrock on which this state is built" [11, p. 23]. From electronic source: "China tacitly encourages emigration. The poverty rate is $128,000,000$ people (less than 1 dollar per day)". [12]

The Middle Kingdom's accession to WTO has contributed a significant development of a foreign trade. Figure 2 represents the schematic overview of this process.

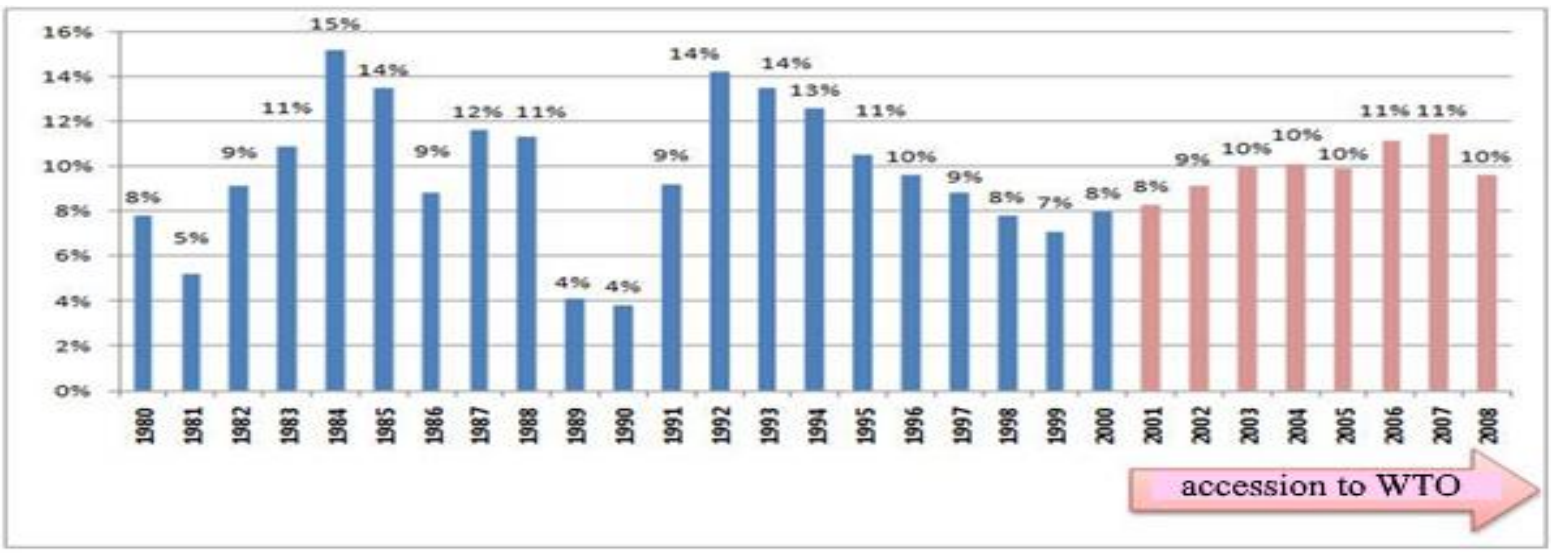

A. Volkonsky reports: "China possesses half the world's currency reserves. In 2012 China got 2 trillion-dollar income at the same time increasing Government consumption expenditure. By 2014 China had considerably reduced the rate of build-up of dollar reserves, substantially increasing investments all over the world. [15]

China's agriculture is characterized by the increase of its productivity, but it faces some challenges because of the water shortages. With regard to space industry, since 2003 China has become a space super-Power. According to Ya. Wang, China's MIC manufactures all sorts of weapons, including thermonuclear devices, ballistic missile submarines and intercontinental ballistic missiles. China managed to finish the construction of a Soviet aircraft carrier purchased from Ukraine and began construction of some more aircraft carriers". [14, p.7] 
China certainly tends to be a super-Power but it has certain civilization features different from the West and the traditional East. E. A. Leksina shows the economic expansion of China: "In order to implement the project "global power" China develops and strengthens its economic capacity reinforcing it by military and strategic development. China's fast-rising becomes the characteristic feature of the global "nitty-gritty of politics" of the XXI century. According to the World Bank, China's economy constitutes more than 9.5 trillion US dollars, that is a half of the American one". [16] Furthermore, E. A. Leksina notes: "In 2012 China was a leader in foreign trade turnover, it was ahead of the US by 50 billion dollars (import and export in China was 3.87 trillion, whereas in the USA it was 3.82 trillion dollars)". [16]

Russian sinologist S. Luzyanin indicated: "In terms of civilization development the major goal of China is to restore historical validity, to get back the status of a regional leader and to achieve the global status..." [17]

The foreign policy strategy of the PRC focuses on a peaceful development, but the People's Republic of China "borders on 14 countries such as Afghanistan, Mongolia, Nepal, DPRK, Pakistan, Russia, Tajikistan and Vietnam". [18] According to S. G. Luzyanin, it is appropriate to comply with the following guidelines in order to modernize foreign policy (eight fundamental principles of Deng Xiaoping's conception):

- watch dispassionately

-strengthen the positions

- respond to changes with confidence

-conceal the abilities

-gain time

-do not attract attention

- avoid taking the lead in international politics

-do concrete actions". [19, p.70]

A. A. Kosorukov suggests: "China is becoming one of the leaders of the developing world which is shifting the emphasis in its foreign policy strategy, relying more on global determinants, with the continuing and valuable role of state and intra-state determinants. The more national resources China has, the more unipolar impact it imposes on the USA, the more active foreign policy it should have. At the present stage the PRC follows a policy of "peaceful development" which aims at building up a peaceful international environment and controlling an internal order. Theessential feature of policy of China is the fight against international isolation by peaceful means, integration of neighboring countries into joint economic projects, economic counteraction to anti-China alliances". [20]

According to A. A. Kosorukov: "There is a concept of "Easternization" in the area of promotion of Chinese "soft power" and getting a leading position in the APR, that concept implies the dominant role of "eastern knowledge". In contrast to "Westernization", the era of the eastern culture, known as "Easternization", is proclaimed. The State systemin China plays a role of a main transporter of external impulses to society, using various approaches based on growing economic power. China's national strength, while retaining its central role in ensuring foreign policy strategy, in 2000-s begins to lose a mobilizing ability and social cohesion, due to both a stable growth of overall national power of China and problems of public support of government initiatives". [20]

A problem of "soft power" is of current importance in China, as illustrated by A. V. Boyarkina in her thesis [21]. As she points out: "Political analysts believe that "soft power" primarily extends to political system, then to national spirit, international image of society...Many Chinese analysts suppose that Chinese "soft power" has more abilities than western countries have, and the reason for this lies in a rich oriental culture". [21]

A. A. Kosorukov points out: "State dominance in the international as well as the domestic arena is typical for China. An important factor which brings together the Chinese society is the policy on large Chinese community abroad. The better feedback from migrants will be built, the more cohesive society in China will be and the more mobilizing ability Chinese society will have. The example of the usage of mobilizing ability with regard to Chinese diaspora is the organization of mass protest actions in 2008 in Italy and Spain against their Government's desire to recognize the independence of Taiwan”. [20]

From geopolitical perspective, China, covering a land area, supports Eurasian cooperation with Europe, Russia and India. China sees its future in cooperation with these countries. E. Grachikov states: "In the XXI century Chinese geopolitics extended beyond its national borders, its active economic activity had an impact on redistribution of spheres of influence of the world power centers (the USA, Europe) to its advantage, withdrawing them from the regions where they had been dominating". [22]

China, being a world export leader, attempts to influence the United States of America economically.

The official website "Ankvitori” publishes the following: 
- new automobiles are purchased in China more actively than anywhere else in the world

- China has the largest amount of foreign exchange reserves

- China is the world's largest gold mining and gold importing country

- China has overtaken the US annual output of engineers and specialists". [23]

Thus, when estimating China and the USA as the world leaders, we can see that the PRC is gaining extensive strength in the region and in the world and it is rapidly moving towards global leadership. Dominance abilities depend on both the history of Sino-American relations and comparative economic indicators.

The economic indicators of net profit are of great importance, since they influence upon the economic development of the country. This results in great significance of implementation of input-output economics and enables to identify GDP at purchasing power parities (PPP) and to identify the structure of GDP itself. PPP makes it possible to estimate the real economy regardless of the US dollar and evaluate the real standard of living. That knowledge of the GDP structure allows to identify the real economy amount, that is the actual amount of production in different branches of industry: extracting and manufacturing.

Nominal GDP rating in bln dollars:

1. US Nominal GDP: $\$ 19.391$ trillion

2. China Nominal GDP: $\$ 12.013$ trillion

GDP based on PPP

1. China GDP: \$23.159trillion

2. US GDP: \$19.391trillion

GDP includes also the value of things consumed by the population, such as food, clothes, housing, utilities, cars, medicines and so on.

Certainly, these are the things of a primary importance, but the power of the country depends upon its army and science as well.

GDP per capita ranking:

1. China GDP: \$1.389.764.000.

3. US GDP: $\$ 325.719 .000$.

GDP (PPP) per capita ranking in dollars:

10. US GDP: $\$ 59.501$.

78. China Nominal GDP: $\$ 16.660$.

As E. Frolov points out: "US manufacturing industry is $15 \%$, agriculture and fishery is $1 \%$, construction is $3 \%$. In total, the real economy constitutes $19 \%$. The rest is trade and various services: manicure, financial services and transportation. In the case of China, its manufacturing industry is $40 \%$, agriculture $-10 \%$, construction $-7 \%$. The real economy constitutes $57 \%$. Thus, China's real economy is three times greater than that of the US». [24]

The major political problem of China is the accession of Taiwan. The electronic source publishes: "China has consistently opposed any forms of official contacts between the USA and theTaiwan authorities. The situation is aggravatedby the statement of the Chinese authorities that the problem of Taiwan cannot wait indefinitely and it is necessary to abandon military action".[24] Therefore, politics sometimes has a negative impact on the economy.

There are certain factors of Chinese leadership which provide social and political changes: its demographic and economic power. The problems of the PRC growth were highlighted at the scientific conference in China in 2007. First of all, these are governance problems. As it is shown in Chinese electronic source: "According to Deng Xiaoping, in order to get socialist democracy, it is necessary to implement popular democracy, go up against the dictatorship of power, decentralize the State, increase the participation of citizens in political life". [25] According to O. V. Litvinov, "China still has low population literacy, that means that it is difficult to implement the principle of a responsible choice since $70 \%$ of the population is represented by semi-literate peasant class". [26]

The PRC demonstrates its own democracy version, a "vertical democracy", whereby interaction is being implemented top-down. D. Neisbit writes: "Vertical democracy in China fully integrates Chinese experience, Chinese history and Chinese vertical models of interaction. During this interaction long-term goals are being formulated and the process of mutual adaptation is taking place. Thus, through appropriate interaction of government and society, in the conditions of centralized state, positive results are possible". [27]

In order to save stability, politics should be based on national culture and Confucianism. Fund of researches of world politics stated: "Western views of Confucian democracy differ from the views of Chinese people. It is obvious, that today the central leadership enjoys the support of the majority of the Chinese population which believes that life is gradually improving. 
While censorship and other limitations do not impact on $90 \%$ of people's daily activities, people are more likely to give the Government the benefit of the doubt and even excuse its excesses and obvious faults since they had not become catastrophic". [28]

From the standpoint of internal aspects of development, China's success is obvious. O. V. Litvinov states: "Living standards of the population have increased. Housing conditions have considerably improved. China has solved the problems of nutrition and housing so far. Despite inflation, which affected a large number of countries, China has managed to save stable RMB exchange rate". [26]

As E.O. Podolko highlights in her thesis, there are global problems in China, like "preventing the proliferation of weapons of mass destruction, fighting against the new threats to humanity (international terrorism, risks of the environmental disaster). The PRC plays a big role in the Asia and Pacific region, where more than a half of the world population live, where the majority of Powers with weapons of mass destruction is situated, which has the highest dynamics of development and which is nowadays one of the main centers of the world competition for markets and resources". [29] From electronic source: "China plays more constructive role in the Central Asian region, it is one of the organizers and active participants of the Shanghai Cooperation Organization". [30]

Bobo Lo's article "China's permanent reset" suggests: "Nowadays it is possible to speak about the shift of the global force to the East and China's emergence as a super-Power of the XXI century. Most of the time after the Cold War China has been focusing on the concept "one super-Power, several super-Powers". Although Beijing often speaks about the "multipolar world order", it has no confidence that this order is a matter for the future. The United States remain undeniable world leader, despite the problems in Iraq and Afghanistan and the influence of global financial crisis". [31]

Website "Russia in global politics" gives an overview of internal problems of China: "Strengthening of domestic political stability is the most important priority of a regional policy. It can shortly sound like "struggle against three evils". That means the strengthening of power of Communist Party in Xinjiang, counteracting Uighur separatism and Islamic radicalism. Strengthening security in the region is considered in terms of domestic policy agenda. Its importance stems from awareness that internal stability of China will be strengthened in case of suspending the activity of Radical Islam and separatist movements. Guided by the idea of "enjoyable neighborhood", Beijing ingratiates itself with Central Asian leaders both at the bilateral level and in multilateral forums, such as the Shanghai Cooperation Organization". [31]

The United Nations National Intelligence Council estimates that "By 2030 China will have the greatest economy in the world and will overtake the USA". [32] According to Ch. Grant, "China will be able to play more important role in international relations, pursue its goals, acting unilaterally, bilaterally or with small groups of allies". [33]

It must be underlined that Confucian values, mainly in social and political sphere, have not undergone any modification. Preservation of traditional ideas demonstrates the desire of the State to create stable and harmonious society. Chita researcher V. A. Abramov points out: "Social harmony and personal wellbeing are achieved through the principles of Confucian public order". [34, p.69] Due to the respect of the authority, the State remains integral and powerful. China's emergence as a global power implies not only economic, but territorial expansion. China will continue to have a growing impact in the future. These are political realities of today.

\section{References}

Mirzayan G. The new face of China. vailableat: http://expert.ru/2012/03/16/novoe-litso-podnebesnoj/ (accessed 21.03.2019).

KondratenkoG.V. Continuation of reforms in China: from a society of "average prosperity" to a harmonious society. RussiaandthePacific, 2009, no. 3, pp. 17-36.

BolyatkoA.V. Security in Asia and the Pacific. Moscow, RAGS, 1998. 67 p.

MikheevV.V. China: threats, risks, developmentchallenges. Moscow, Carnegie Moscow center, 2005. 647p.

Andreev E. Doubling of China: what will bring the abolition of the rule "one family — one child".Availableat: https://www.rbc.ru/opinions/society/11/11/2015/-5642d7709a794773d004037d (accessed09.10.2018).

Tszo DapehI. It is necessary to discuss so that it is clear. Du Shu, 2008, no. 1, pp. 13-14.

Borokh O., Lomanov A. China's modest charm. ProetContra, 2007, no. 6(39), pp. 41-60.

Sin' LI. On the " Chinese model". A world of change, 2011, no. 1, pp. 75-87.

MVF: GDP at purchasing power parity of China for the first time became more than the US. Available at: https://tass.ru/ekonomika/1494526 (accessed 02.02.2019).

Laperdina V.V. Analysis of China's economic growth at the turn of the century. The problem of estimation of GDP. Moscow, Instituteofeconomics, 2009. 51p. 
AksenovaK.I. China's foreign policy: from the utopia of a non-polar world to the Chinese "reset". Bulletin of RUDN, political Science series, 2012, no. 1, pp. 22-27.

Barboza D. China Passes Japan as Second-Largest Economy. TheNewYorkTimes. Available at: https://www.nytimes.com/2010/08/16/business/global/16yuan.html (accessed 02.02.2019).

VolkonskyV. A. dramaofspiritualhistory: non-economicfounrationsoftheeconomiccrisisEconomicissue, 2004, no. 9, pp. $155-157$.

Van YA. The level and trends of development of innovation and investment potential of agriculture in China. Vestnik of the Grodno state University named Yanka Kupala. Series 5: Economics. Sociology. Biology, 2012, no. 1 (125), pp. 6-14.

VolkonskiiV. Dramaofspiritualhistory: non-economicfoundationsoftheeconomiccrisis Availableat: https://ecfor.ru/publication/vneekonomicheskie-osnovaniya-ekonomicheskogo-krizisa/ (accessed 21.03.2019).

Leksina E.A. The problem of global leadership: American and Chinese approaches. International scientific Bulletin. Penza, limited liability Company "Information and technical Department of Academy of natural Sciences", 2015. 112 p.

LuzyaninS. ChinaandtheXVIIICongressoftheCPC.Moscow, Obozrevatel, 2013, no 1, pp. 54-60.

Deputy Chairman of the PRC called the priority task of the CPC in the field of diplomacy to ensure a peaceful environment.Availableat: http://russian.people.com.cn/31521/7264054.html. (accessed 02.02.19).

LuzyaninS.G. Chinaandtheworld: fromregionaltoglobal.Moscow, Obozrevatel, 2011, no. 9, pp. 76-85.

Kosorukov A.A. China's strategy at the beginning of the XXI century: reaching the global level.Availableat: http://enotabene.ru/nb/article_13390.html (accessed 09.02.2019).

BoyarkinaA.V. "Soft power" as a political tool for the implementation of foreign policy at the turn of XX - XXI centuries.Availableat: https://www.dvfu.ru/upload/medialibrary/3d2/\%D0\%90\%D0\%B2\%D1\%82\%D0\%BE\%D1\%80\%D0\%B5\%D1\%84\%D0\%B5\%D1\%80\%D0\%B0\%D1\%82\%20\%D0\%91\%D0\%BE\% D1\%8F\%D1\%80\%D0\%BA\%D0\%B8\%D0\%BD\%D0\%BE\%D0\%B9\%20\%D0\%90.\%D0\%92..pdf (accessed09.01.2019).

Grachikov E. China in world politics.Availableat: http://www.geopolitica.ru/article/kitay-v-mirovoypolitike (accessed02.02.19).

China and the US: the new leader of the world economy.Availableat: http://anvictory.org/blog/2013/02/11/kitaj-issha-smena-lidera-mirovoj-ekonomiki/ (accessed04.03.2019).

FrolovE. GDP of Russia, USA and China. Unexpected comparison.Availableat: https://topcor.ru/732-vvp-rossiissha-i-kitaya-neozhidannoe-sravnenie.html (accessed 14.01.2019).

Chinese democracy. Availableat: https://baike.baidu.com/item/中国民主政治/16846354 (accessed 11.02.2019).

LitvinovO.V. China'spathtodemocracy.Moscow, Scientificbook, 2004, pp. 128-130.

Neisbit D. Vertical democracy in China. International process. Moscow, Scientific and educational forum on international relations, 2009. Vol. 7. no. 3, pp. 45-46.

Bkhutalingam R. "China 2020: a Confucian democracy?" Russia in global politics.] Moscow, Fund of researches of world politics, 2011. Vol. 9, no. 1,p. 144.

Podolko E.O. Evolution of foreign policy concept in the People's Respublic of China.. Diss. kand. polit. Nauk. Moscow. 2006. 230p.

The Chinese factor in modern international relationsAvailableat: http://www.synologia.ru/ (accessed 04.03.2019).

Bobo Lo. China's "permanentreset".Availableat: https://globalaffairs.ru/number/Postoyannaya-perezagruzka-Kitaya15017 (accessed 14.01.2019).

Global trends 2030: Alternative worlds, fifth edition of the national intelligence Council reports.Availableat: http://eurasian-defence.ru/sites/default/files/DS/Documents/global-trends-2030-rus.pdf (accessed 19.10.2019).

GrantCH. Russia, China and global governance issues. Moscow, the Center of Europe. reforms, 2012. 162 p.

Abramov V.A. Globalizing China: aspects of social and cultural dimension. Moscow, Eastern book, 2010. 239p.] 